\title{
Educação Médica e justiça: um desafio para o século 21
}

\section{Medical Education and justice: a challenge for the 21st century

A profissão médica é historicamente associada a práticas solidárias, virtuosas ou mesmo compassivas. A dedicação do médico ao doente e o envolvimento com os diversos aspectos da vida deste, incluindo dinâmicas da vida familiar, tornam esse profissional do passado um modelo em que muitos (ainda) se inspiram. Em especial porque, associada a esta prática tipicamente liberal, havia outra, freqüentemente caritativa, praticada em unidades de saúde vinculadas à Igreja Católica. O cuidado oferecido pelo médico era marcado por uma relação pessoal intensa, com um acompanhamento lado a lado que expressava, muitas vezes, a falta de possibilidades concretas de intervenção no processo saúde-enfermidade. Estar ao lado, aplicando compressas e sanguessugas e realizando sangrias, era, com freqüência, tudo o que se sabia ser possível fazer em outros tempos. Tempos em que todos os instrumentos de trabalho dos médicos cabiam numa pequena maleta.

Mas o mercado, inclusive o da saúde, mudou no Brasil e no mundo. Entre essas mudanças destaca-se a diminuição do espaço ocupado por práticas liberais típicas, o crescimento do assalariamento nos setores público e privado, e a intermediação empresarial na prática liberal (através das empresas de medicina de grupo, de seguros-saúde e mesmo das cooperativas médicas que operam sob o sistema de pré-pagamento do usuário).

Observou-se também um distanciamento das características que, um dia, associaram a prática médica ao sacerdócio. Dito de outra forma: as bases emocionais ou afetivas da prática médica foram substituídas pelo profissionalismo e racionalismo. Da compaixão, da empatia "natural", passamos à compreensão de que a justiça social e outros valores são (ou devem ser) fundamentados em bases ideológicas ou enfatizamos nossa técnica, acreditando na neutralidade do uso da ciência. Associando-se o discurso da justiça social a idéias de apenas um segmento político, criou-se uma falsa idéia de que a preocupação com a justiça está associada a determinado discurso político e a um falso antagonismo irreconciliável entre indivíduo e coletividade.

Hoje, o médico não pode mais ser formado tendo as duas antigas perspectivas como objetivo: nem apenas a compaixão, nem apenas o racionalismo/tecnicismo. Os tempos atuais demandam mais do médico: demandam compromisso ético com o indivíduo, enfermo ou não, e com a comunidade. Do médico demanda-se um compromisso moral com a humanidade, que implica um comportamento eticamente engajado no combate às determinantes da iniqüidade em saúde. Às diferenças em saúde que são provocadas pelo "comportamento prejudicial à saúde no qual o grau de escolha de estilos de vida seja severamente restrito; exposição a condições de vida e de trabalho insalubres e estressantes; acesso inadequado a serviços essenciais de saúde e a outros serviços básicos; e a mobilidade social relacionada com 
a saúde e que envolve a tendência de pessoas doentes caírem na escala $\operatorname{social}^{\prime 1}$ (p. 5). Tais diferenças não são apenas desnecessárias e evitáveis, mas também injustas. Dados empíricos assinalam ainda, como Whitehead destaca, que na América Latina e no Caribe os pobres usam menos recursos públicos que os setores sociais mais abastados.

Promover esse debate com docentes e discentes é uma das tarefas inadiáveis da escola médica neste início de século.

O Sistema Único de Saúde (SUS) é uma conquista advinda do movimento de Reforma Sanitária. Desde a promulgação da Constituição de 1988, vários passos foram dados para a sua criação e implementação, mas ainda existem muitos nós que permeiam o cotidiano do fazer saúde. Em sua expansão, o SUS herdou um aparato tecnológico que priorizou a manutenção do modelo médico-centrado, mesmo que suas diretrizes sugiram a inversão do modelo de atenção, com investimento na atenção básica. Nesse sentido, a formação apresenta diversos desafios a superar no que diz respeito às desigualdades existentes, pois o cenário de saúde é permeado por intensas desigualdades sociais, intelectuais e de governabilidade.

As estratégias de formação profissional ao longo dos anos têm passado por uma série de desafios. Na atualidade, são cada vez mais exigidos conhecimentos técnicos e humanos abrangentes que obrigam os profissionais a buscarem na formação e no aperfeiçoamento formas de atender às exigências do mercado. As universidades, voltadas para a pesquisa, com seus currículos das primeiras décadas do século 20 , ainda incorporam a idéia de que a competência prática se torna profissional quando seu instrumental de solução de problemas é baseado no conhecimento sistemático, de preferência científico. Assim, o currículo profissional normativo apresenta, em primeiro lugar, a ciência básica, em seguida, a ciência aplicada. Só no final da formação é oferecido um espaço de ensino prático no qual se espera que os estudantes aprendam a aplicar o conhecimento baseado na pesquisa aos problemas da prática cotidiana.

Notamos que a discussão sobre a formação de recursos humanos cresce nos fóruns de debates (entre eles, os congressos da Abem, da Rede Unida e da Abrasco), e o tema continua a ser um dos maiores desafios do SUS. O despreparo dos profissionais recém-formados para atuarem na complexidade do sistema de saúde, compreendendo sua gestão com a ação do controle social, é uma constatação freqüente. E, ainda, o perfil dos novos profissionais repete formas inadequadas de relação com os usuários e pouca capacidade de cuidar de pessoas e coletivos.

Não se trata de tarefa exclusiva de educadores, mas de uma responsabilidade das instâncias e unidades técnicopolíticas de gestão dos serviços de saúde e da sociedade civil. As propostas de inserção do estudante de Medicina nesse processo desde o início do curso podem garantir uma escola integrada com o serviço de saúde com gestão democrática e horizontalizada, partilhada com o SUS, que problematize as questões de saúde de sua região, seu país e seu mundo, e que atue na proposição de mudanças com e para a sociedade.

Afinal, acreditamos que um dos maiores desafios da saúde (e da medicina) é voltar a descobrir a complexidade, a delicadeza e a sensibilidade do mundo. Um mundo de graves desigualdades e gerador de pobreza. Um mundo que exige, de forma urgente, estratégias reais e profundas de desenvolvimento humano.

\section{REFERÊNCIA}

1. Whitehead M. The concepts and principles of equity and health. World Health Organization, Regional Office for Europe 1991 p. 5. (WHO document EUR/ICP/RPD 414. Unpublished) 